\title{
PERSENTASE KARKAS DAN LEMAK ABDOMEN BROILER YANG DIBERI PAKAN KOMBINASI HERBAL DENGAN MINERAL ZINK
}

\author{
Mursye N. Regar*, Youdhie H.S. Kowel dan Merci R. Waani \\ Fakultas Peternakan Universitas Sam Ratulangi, Manado, Sulawesi Utara
}

\begin{abstract}
ABSTRAK
Penelitiani ini dilakukan untuk mengetahui kualitas karkas broiler yang diberi pakan kombinasi herbal dengan mineral zink. Seratus ekor broiler dibagi secara acak menggunakan Rancangan Acak Lengkap (RAL) ke dalam 4 perlakuan, masing-masing perlakuan diulang sebanyak 5 kali sehingga terdapat 20 unit percobaan, setiap unit percobaan terdiri dari 5 ekor DOC. Pakan perlakuan terdiri dari R1= Ransum basal, R2= Ransum basal + serbuk kunyit 1,5\% + ZnO 180 ppm, R3=Ransum basal + serbuk bawang putih 2,5\% + ZnO 180 ppm, R4= Ransum basal + antibiotik. Peubah yang diamati persentase karkas dan lemak abdomen. Hasil penelitian menunjukkan kombinasi herbal dengan mineral zink memberikan pengaruh nyata $(\mathrm{P}<0.05) \quad$ terhadap persentase karkas dan lemak abdomen. Disimpulkan bahwa kombinasi kunyit dengan mineral zink maupun kombinasi bawang putih dengan mineral zink menghasilkan persentase karkas dan lemak abdomen yang baik
\end{abstract}

Kata Kunci : broiler, herbal, zink, karkas, lemak abdomen

*Kosepondensi (corresponding author)

Email : mursyeregar@unsrat.ac.id

\section{ABSTRACT} FAT PERCENTAGES IN BROILERS FED RATION COMBINED WITH HERBAL DAN ZINC MINERAL Study was done to evaluate carcass quality of broilers fed ration combined with herbal and zinc mineral. Hundred broilers were randomly divided into four treatments with five replications in each treatment. Each unit was placed five day old chicks. Treatments were consisted of basal ration (R1), basal ration added with $1.5 \%$ of turmeric and $180 \mathrm{ppm}$ of Zinc (R2), basal ration added with $2.5 \%$ of white onion and $180 \mathrm{ppm}$ of Zinc (R3), and basal ration added with anti biotic (R4). Results showed that combination of herbal and zinc mineral affected significantly the carcass and abdomen fat in broilers. Therefore, it can be concluded that combinations of turmeric or white onion and zinc mineral produced ideal carcass and abdomen fat in broilers.

Key Words: Abdomen fat, broiler, carcass, herbal, zinc.

\section{PENDAHULUAN}

Budaya mengkonsumsi pangan yang sehat merupakan faktor yang sangat penting dalam menghasilkan sumber daya manusia yang berkualitas. Daging broiler merupakan salah satu pangan yang dikonsumsi secara luas, sebagai sumber 
protein dan lemak dalam jumlah besar di Indonesia untuk semua usia (anak-anak maupun dewasa) karena mudah diperoleh dan harganya relatif murah.

Pemeliharaan broiler pada umumnya masih menggunakan obatobatan, dan ransum imbuhan seperti antibiotik dan hormon untuk mencapai produk yang optimal. Penggunaan antibiotik dalam ransum ternak bertujuan sebagai pemacu pertumbuhan, untuk memperbaiki efisiensi penggunaan ransum dan pencegahan terhadap kemungkinan infeksi patogen. Namun, penggunaan antibiotik telah dibatasi penggunaannya karena residu antibiotik akan terbawa dalam produk ternak (daging, susu dan telur), yang akan berbahaya bagi konsumen.

Penggunaan herbal dalam ransum menjadi salah satu alternatif untuk mengatasi masalah tersebut, yaitu dengan menggunakan herbal kunyit dan bawang putih yang dikombinasikan dengan mineral zink. Kunyit dimanfaatkan untuk menambah cerah atau warna kuning kemerahan pada kuning telur, jika dicampurkan pada ransum ayam, dapat menghilangkan bau kotoran ayam dan menambah berat badan ayam, juga minyak atsiri kunyit bersifat antimikroba (Winarto, 2003). Komponen aktif dalam bawang putih, allicin merupakan zat aktif yang mempunyai daya bunuh pada bakteri dan anti radang; alliin merupakan suatu asam amino antibiotik dan menurunkan kolesterol darah dan daging broiler (Jaya, 1997). Mineral zink dalam bentuk zink inorganik mempunyai fungsi meningkatkan performans dan respon imun terhadap broiler (Ali et al., 2003).

\section{MATERI DAN METODE PENELITIAN}

Penelitian ini menggunakan 100 ekor DOC broiler yang ditempatkan dalam 20 unit kandang, secara acak. Tiap unit kandang ditempati 5 ekor broiler yang dilengkapi dengan tempat pakan dan minum. Rancangan penelitian yang digunakan adalah Rancangan Acak Lengkap (RAL), terdiri dari 4 perlakuan dan 5 ulangan. Data yang diperoleh dianalisis sidik ragam (ANOVA), bila terdapat perbedaan yang nyata dilakukan uji lanjut dengan Uji Tukey. 
Tabel 1. Komposisi Nutrien Pakan Perlakuan

\begin{tabular}{lccccccc}
\hline Perlakuan & $\begin{array}{c}\text { ME } \\
\text { Kcal/kg }\end{array}$ & $\begin{array}{c}\text { Protein } \\
\text { Kasar } \\
(\%)\end{array}$ & $\begin{array}{c}\text { Serat } \\
\text { Kasar } \\
(\%)\end{array}$ & $\begin{array}{c}\text { Lemak } \\
\text { Kasar } \\
(\%)\end{array}$ & $\begin{array}{c}\text { Ca } \\
(\%)\end{array}$ & $\begin{array}{c}\text { P } \\
(\%)\end{array}$ & $\begin{array}{c}\text { Zn } \\
(\%)\end{array}$ \\
\hline R1 & 3073 & 22,62 & 3,21 & 10,21 & 1,80 & 0,72 & 0,005 \\
R2 & 3235 & 22,38 & 3,11 & 9,46 & 1,32 & 0,62 & 0,017 \\
R3 & 3188 & 22,35 & 2,73 & 11,15 & 1,90 & 0,61 & 0,015 \\
R4 & 3073 & 22,62 & 3,21 & 10,21 & 1,80 & 0,72 & 0,005 \\
\hline
\end{tabular}

Pakan yang digunakan adalah pakan komersial, yang selanjutnya disebut ransum basal. Ransum basal kemudian dicampur dengan serbuk kunyit, serbuk bawang putih, dan mineral zink dalam bentuk $\mathrm{ZnO}$. Formula pakan perlakuan terdiri dari : R1= Ransum basal, R2= Ransum basal + serbuk kunyit 1,5\% + ZnO 180 ppm, R3=Ransum basal + serbuk bawang putih 2,5\% + ZnO 180 ppm, R4= Ransum basal + antibiotik. Penggunaan mineral zink adalah dalam bentuk $\mathrm{ZnO}$ (mengandung $80 \% \mathrm{Zn}$ ), mengingat $\mathrm{ZnO}$ tidak bersifat toksik jika digunakan dalam taraf yang relatif tinggi dan mudah didapat di pasaran dengan harga yang relatif murah. Antibiotik yang digunakan adalah antibiotik komersial dengan dosis pengobatan selama 3 hari, diberikan dalam air minum. Variabel yang diukur adalah persentase karkas dan lemak abdomen.

\section{HASIL DAN PEMBAHASAN}

Karkas broiler adalah bagian tubuh ayam yang disembelih lalu dikeluarkan isi perut, kaki, leher, kepala, bulu, dan darah. Sedangkan Lemak Abdominal adalah lapisan lemak yang terdapat disekitar gizzard dan lapisan antara otot abdominal dan usus (Salam et al., 2013). Data hasil penelitian kombinasi herbal dengan mineral zink dalam ransum terhadap kualitas karkas broiler dapat dilihat pada Tabel 2.

\section{Bobot Karkas}

Rataan bobot karkas hasil penelitian berkisar 1040,51 $\pm 33,89$ gram -

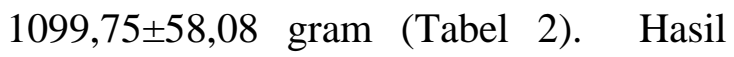
analisis keragaman menunjukkan bahwa pemberian komninasi herbal dengan mineral zink dalam ransum menunjukkan perbedaan tidak nyata $(\mathrm{P}>0.05)$ terhadap bobot karkas. Bobot karkas dipengaruhi oleh bobot hidup, sehingga bobot hidup yang besar akan diikuti pula oleh bobot karkas yang besar pula, dan sebaliknya. 
Tabel 2. Rataan Bobot Karkas, Persentase Karkas dan Lemak Abdomen

\begin{tabular}{lllll}
\hline \multirow{2}{*}{\multicolumn{1}{c}{ Peubah }} & \multicolumn{4}{c}{ Perlakuan } \\
\cline { 2 - 5 } & \multicolumn{1}{c}{ R1 } & \multicolumn{1}{c}{ R2 } & \multicolumn{1}{c}{ R4 } \\
\hline Bobot Karkas (gram) & $1040,51 \pm 33,98$ & $1045,88 \pm 29,62$ & $1072,08 \pm 32,98$ & $1099,75 \pm 58,08$ \\
Persentase Karkas (\%) & $71,27 \pm 2,78^{\text {a }}$ & $63,63 \pm 5,79^{\mathrm{b}}$ & $68,80 \pm 1,64^{\mathrm{ab}}$ & $67,61 \pm 3,41^{\mathrm{ab}}$ \\
Persentase Lemak Abdomen (\%) & $2,15 \pm 0,13^{\mathrm{a}}$ & $1,73 \pm 0,15^{\mathrm{b}}$ & $1,81 \pm 0,07^{\mathrm{b}}$ & $1,96 \pm 0,19^{\mathrm{ab}}$ \\
\hline
\end{tabular}

Keterangan : Superskrip berbeda pada baris yang sama menunjukkan perbedaan yang nyata $(\mathrm{P}<0.05)$

Wahju (1992) mengatakan bahwa tingginya bobot karkas ditunjang oleh bobot hidup akhir sebagai akibat pertambahan bobot hidup ternak bersangkutan. Beberapa faktor yang mempengaruhi bobot karkas yaitu umur, jenis kelamin, bobot potong, besar dan konformasi tubuh, perlemakan, kualitas dan kuantitas ransum serta strain yang dipelihara.

\section{Persentase Karkas}

Hasil analisis keragaman pemberian kombinasi herbal dengan mineral zink dalam ransum menunjukkan perbedaan yang nyata $(\mathrm{P}<0.05)$ terhadap persentase karkas. Rataan persentase karkas yang diperoleh dalam penelitian ini berkisar antara $63,63 \pm 5,79 \%$ sampai $71,27 \pm 2,78 \%$ (Tabel 2). Hal ini sesuai dengan pendapat North dan Bell (1992) bahwa persentase karkas broiler bervariasi antara $65-75 \%$ dari bobot badan, semakin berat ayam yang dipotong, maka karkasnya semakin tinggi pula. Persentase karkas broiler berkisar $65,35 \%$ sampai $66,56 \%$ (Daud et al., 2007). Uji Tukey menunjukkan perlakuan $\mathrm{R} 1$ nyata $(\mathrm{P}<0.05)$ lebih tinggi dari R2 tetapi tidak berbeda nyata dengan R3 dan R4. Sementara perlakuan R3 dan R4 sama dengan R1 dan R2. Hal ini menunjukkan bahwa penggunaan kombinasi herbal dengan mineral zink menghasilkan persentase karkas yang sama dengan pakan basal dan pakan dengan antibiotik

Peningkatan persentase karkas disebabkan oleh peningkatan berat badan, sebab semakin tinggi berat badan semakin besar persentase karkas. Hal ini menunjukkan bahwa bawang putih (Allium sativum) bersifat sebagai growth promotor. Zat yang diduga berfungsi sebagai growth promotor adalah scordinin. Pengaruh fisiologis scordinin yang disuntik-kan pada tikus ternyata mampu meningkatkan pertumbuhan dan berat badan dibanding control (Hidajati, 2005).

Mide (2012) melaporkan bahwa penambahan tepung rimpang kunyit di dalam pakan secara tidak langsung berpengaruh pada konsumsi pakan dan absorbsi zat-zat makanan sehingga dapat 
membentuk produksi daging, dan persentase karkas daging akan meningkat.

\section{Persentase Lemak Abdomen}

Hasil analisis keragaman pemberian kombinasi herbal dengan mineral zink dalam ransum menunjukkan perbedaan yang nyata $(\mathrm{P}<0.05)$ terhadap lemak abdomen. Rataan persentase karkas yang diperoleh dalam penelitian ini berkisar antara $1,73 \pm 0,15 \%$ sampai $2,15 \pm 0,13 \%$ (Tabel 2). Hal ini hampir mendekati pendapat Griffits \& Summers (1978) yang mengatakan bahwa ayam broiler muda mengandung kira-kira $3 \%$ lemak abdominal dari total bobot badan. Uji Tukey menunjukkan perlakuan R1 nyata $(\mathrm{P}<0.05)$ lebih tinggi dari perlakuan $\mathrm{R} 2$ dan $\mathrm{R} 3$, tetapi tidak berbeda nyata dengan perlakuan R4, sementara antara perlakuan $\mathrm{R} 2, \mathrm{R} 3$ dan R4 tidak terdapat perbedaan. Hal ini menunjukkan bahwa penggunaan kombinasi herbal dengan mineral zink dapat menurunkan persentase lemak abdomen.

Darwis et al. (1991) mengatakan bahwa zat kurkuminoid mempunyai khasiat anti bakteri dan dapat merangsang dinding kantung empedu untuk mengeluarkan cairan empedu sehingga dapat memperlancar metabolisme lemak. Cairan empedu adalah suatu cairan garam berwarna kuning kehijauan yang mengandung kolesterol, fosfolifid, lesitin serta pigmen empedu. Empedu mengandung sejumlah garam hasil dari pencampuran antara natrium dan kalium dengan asam-asam empedu (asam glikokolat dan taurokolat). Garam-garam ini akan bercampur dengan lemak di dalam usus halus untuk membentuk micelles, jika micelles sudah terbentuk akan menurunkan tegangan antara permukaan lemak,dan gerakan mencampur pada saluran pencernaan berangsur-angsur dapat memecah globulus lemak menjadi partikel yang lebih halus sehingga lemak dapat dicerna. Kurkuminoid yang terdapat dalam kunyit dapat menurunkan lemak abdomen. Peningkatan dan penurunan bobot lemak abdominal berbanding lurus dengan peningkatan dan penurunan bobot badan ayam (Pratikno, 2011). Ramuan herbal mengandung zat bioaktif berupa minyak atsiri dan kurkumin yang dapat menurunkan lemak abdominal pada broiler. Minyak atsiri dan kurkumin yang dapat merangsang dinding kantong empedu dengan menetralkan kondisi asam dari saluran usus dan mengurangi pengemulsian lemak sehingga pembentukan lemak berkurang (Jumiati et al., 2017).

\section{KESIMPULAN}

Kombinasi herbal kunyit dengan mineral zink maupun kombinasi herbal 
bawang putih dengan mineral zink dalam pakan memberikan persentase karkas dan lemak abdomen yang baik.

\section{DAFTAR PUSTAKA}

Ali, S.A., M.A.M. Sayed, S.A. El-wafa, A.G, Abdallah. 2003. Performance and immune response of broiler chick as affected by Methionine and Zinc or Commercial Zink-methionine Supplementations. J Egypt Poult Sci. 23(3): 523-540.

Darwis, S.N, A.B.D. Modjo dan S. Hasiyah.1991. Tanaman Obat Familia Zingiberaccae. Badan Penelitian dan Pengembangan Pertanian Industri. Bogor.

Daud, M. W.G. Piliang dan P. Kompiang. 2007. Persentase dan kualitas karkas ayam pedaging yang diberi probiotik dan prebiotik dalam ransum. JITV. 12(3): 167-174.

Griffiths, L.L. dan J.D. Summers. 1978. Studies on Abdominal Fat with Four Commercial Strainof Male Broiler Chicken. Poultry Sci.

Hidajati, N. 2005. Peran Bawang Putih (Allium sativum) dalam Meningkatkan Kualitas Daging Ayam Pedaging. Media Kedokteran Hewan Vol.21(1): 3234.

Jaya, I.N.S. 1997. Pengaruh Penambahan Bawang Putih (Allium sativum L.) dalam Ransum pada Kadar Kolesterol Ayam Broiler. Tesis. Program Pascasarjana, Institut Pertanian Bogor. Bogor.

Jumiati, S. Nuraini dan R. Aka. 2017. Bobot potong, karkas, giblet dan lemak abdominal ayam broiler yang diberi Temulawak (Curcumaxzanthorrhiza, Roxb.) dalam pakan. JITRO. 4(3).

North, M.O. dan D.D. Bell. 1992. Commercial Chicken Production Manual. $2^{\text {nd }}$ Ed. The Avi Publishing Co. Inc. Wesport. Conecticut. New York.

Pratikno, H. 2011. Lemak abdominal ayam broiler (Gallus sp) karena pengaruh Ekstrak Kunyit (Curcuma domestica Vohl.). Bioma Vol. 3(1):

Salam, S, A. Fatahilah, D. Sunarti dan Isroli. 2013. Bobot karkas dan lemak abdominal broiler yang diberi tepung jintan hitam (Nigella sativa) dalam ransum selama musim panas. J. Sains Peternakan II(2):84-89

Wahju, J. 1992. Ilmi Nutrisi Unggas. Cetakan ke-3. Gadjah Mada University Press. Yogyakarta. 